\title{
Changes in sea urchins and kelp following a reduction in sea otter density as a result of the Exxon Valdez oil spill
}

\author{
Thomas A. Dean ${ }^{1, *}$, James L. Bodkin ${ }^{2}$, Stephen C. Jewett ${ }^{3}$, Daniel H. Monson ${ }^{2}$, \\ Dennis Jung ${ }^{1}$
}

\author{
${ }^{1}$ Coastal Resources Associates, Inc., 1185 Park Center Dr., Ste. A, Vista, California 92083, USA \\ ${ }^{2}$ Biological Resources Division, U.S. Geological Survey, Alaska Science Center, 1011 E. Tudor Rd., Anchorage, \\ Alaska 99503, USA \\ ${ }^{3}$ School of Fisheries and Ocean Sciences, University of Alaska Fairbanks, 200 O'Neill Building, Fairbanks,
} Alaska 99775, USA

\begin{abstract}
Interactions between sea otters Enhydra Iutris, sea urchins Strongylocentrotus droebachiensis, and kelp were investigated following the reduction in sea otter density in Prince William Sound, Alaska, after the Exxon Valdez oil spill in 1989. At northern Knight Island, a heavily oiled portion of the sound, sea otter abundance was reduced by a minimum of $50 \%$ by the oil spill, and from 1995 through 1998 remained at an estimated $66 \%$ lower than in 1973 . Where sea otter densities were reduced, there were proportionally more large sea urchins. However, except in some widely scattered aggregations, both density and biomass of sea urchins were similar in an area of reduced sea otter density compared with an area where sea otters remained about 10 times more abundant. Furthermore, there was no change in kelp abundance in the area of reduced sea otter density. This is in contrast to greatly increased biomass of sea urchins and greatly reduced kelp density observed following an approximate $90 \%$ decline in sea otter abundance in the western Aleutian Islands. The variation in community response to a reduction in sea otters may be related to the magnitude of the reduction and the non-linear response by sea urchins to changes in predator abundance. The number of surviving sea otters may have been high enough to suppress sea urchin populations in Prince William Sound, but not in the Aleutians. Alternatively, differences in response may have been due to differences in the frequency or magnitude of sea urchin recruitment. Densities of small sea urchins were much higher in the Aleutian system even prior to the reduction in sea otters, suggesting a higher rate of recruitment.
\end{abstract}

KEY WORDS: Enhydra lutris · Strongylocentrotus droebachiensis · Prince William Sound · Alaska · Keystone species · Top-down control

\section{INTRODUCTION}

One of the most well-known paradigms in ecology is that involving interactions between sea otters Enhydra lutris, sea urchins Strongylocentrotus spp., and kelp (reviewed in Estes \& Duggins 1995). Sea otters are considered keystone predators within coastal marine systems of the North Pacific that exert strong top-down control on the structure of the nearshore community

•E-mail: coastal_resources@compuserve.com
(Power et al. 1996). Throughout their range, sea otters reduce densities of large sea urchins, which are a preferred prey. In rocky habitats, this leads to higher densities of kelp, which are less grazed by sea urchins. Thus, the paradigm holds that there are 2 states within the system: one with sea otters, few large sea urchins, and dense kelp; and the other without sea otters, an abundance of large sea urchins, and less dense kelp.

The evidence for the paradigm is mostly of 2 sorts: observations of sea urchins and kelp in (1) nearby areas with and without sea otters (Estes \& Palmisano 1974. Estes et al. 1978, Duggins 1980, Breen et al. 1982, Estes 
\& Duggins 1995), and (2) in a given area before and after recolonization by sea otters after decades of absence (Lowry \& Pearse 1973, Laur et al. 1988, Watson 1993, Estes \& Duggins 1995, Kvitek et al. 1998). Both types of evidence have led to similar conclusions regarding the generalized effect of the sea otter foraging on kelp forest community structure. Fewer studies have examined the transitions during recolonization by sea otters (Laur et al. 1988, Watson 1993, Estes \& Duggins 1995, Konar 2000, in this issue), and only 2 recent studies (Estes et al. 1998, Konar 2000) have examined community response to a reduction in the abundance of sea otters. Yet it is these sorts of observations of dynamic systems that may provide greater understanding of the role of sea otters, and keystone predators in general, in determining community structure.

Here, we describe changes in populations of sea otters, sea urchins Strongylocentrotus droebachiensis, and kelp in Prince William Sound, Alaska, following the Exxon Valdez oil spill. We present evidence that sea otter densities in heavily oiled parts of the sound remained reduced for at least $9 \mathrm{yr}$ following the spill. We compare sea urchin populations in these areas to those in an unoiled part of the sound, where sea otter densities were about 6 to 15 times higher after the spill, and examine possible cascading effects on benthic algae. We specifically ask (1) Was the observed reduction in sea otter density, maintained over a period of $9 \mathrm{yr}$, sufficient to result in changes to sea urchins or kelp? and (2) What do observed changes, or lack thereof, suggest regarding the generality of the sea otter-sea urchin-kelp paradigm and the role of keystone predators?

\section{THE SYSTEM}

Intense hunting pressure caused sea otters to become nearly extinct during the late 19th century (Riedman \& Estes 1988). However, a small remnant population persisted in Prince William Sound (Lensink 1962) and this population expanded during the 1960s and early 1970 s. By the late 1980 s, sea otters had occupied western Prince William Sound, the area most affected by the oil spill, for at least 2 decades and populations appeared relatively stable (Bodkin et al. 2000). Sea otters in the sound feed mostly on clams, crabs and mussels (Calkins 1978, Garshelis et al. 1986, Doroff \& Bodkin 1994), but occasionally prey on sea urchins (Doroff \& Bodkin 1994). There are few data on sea urchin densities prior to the expansion of sea otter populations. Intertidal surveys conducted following the 1964 earthquake found sea urchins were 'regular but uncommon' (Haven 1971). However, a survey conducted in 1984 in a portion of the sound not yet oc- cupied by sea otters found high density patches of large sea urchins in the shallow subtidal (D. B. Irons, J.L.B. and G. R. VanBlaricom unpubl. data). Other diver surveys in shallow water $(<30 \mathrm{~m})$ conducted in 1975-76 and 1979, in parts of the sound occupied by sea otters, found few sea urchins (Rosenthal et al. 1977 , 1982). Much of the nearshore zone is densely vegetated by kelps Agarum clathratum, Laminaria saccharina, Laminaria bongardiana, and Nereocystis luetkeana (Rosenthal et al. 1977, Dean et al. 1996b).

In 1989, the Exxon Valdez oil spill killed an estimated 1000 to 2800 sea otters (Garrott et al. 1993). Most of the deaths occurred within Prince William Sound (Garshelis 1997) and mortality was particularly high around northern Knight Island, where an estimated $90 \%$ of the sea otters were oiled (Bodkin \& Weltz 1990, Bodkin \& Udevitz 1994). There was no apparent effect of oil on sea otters within the largely unoiled eastern sound and Montague Island areas.

There was no detectable reduction in sea urchin density as a direct result of the oil spill, and impacts on subtidal kelp were minimal. In surveys conducted a year after the spill, sea urchins were rare at both oiled and unoiled sites, and there was no difference in density between sites (Dean et al. 1996a). Surveys conducted in 1990, $1.5 \mathrm{yr}$ after the spill, indicated that there were proportionally more small plants of some kelp species and higher densities of Laminaria saccharina at oiled than at unoiled sites (Dean et al. 1996b). However, there were no differences in either percent cover or biomass for all kelp species combined.

\section{METHODS}

Estimates of sea otter abundance. Sea otter densities were compared between a heavily oiled $168 \mathrm{~km}^{2}$ area around northern Knight Island and an unoiled $90 \mathrm{~km}^{2}$ area near Montague Island (Fig. 1). Extensive markrecapture efforts indicated that there was no movement of sea otters between these areas (J.L.B. unpubl. data). The pre-spill estimate of sea otter abundance is based on data from a sound-wide aerial census conducted in June 1973 (Pitcher 1975). We estimated abundance within our study areas by taking subsets of the census data corresponding to these areas. Postspill estimates are from aerial surveys conducted in July or August in each year from 1993 to 1998 using methods described in Bodkin \& Udevitz (1999). A single survey was conducted in 1993 and 1994. Thereafter, 4 to 6 replicate surveys were conducted each year.

There are no reliable estimates of sea otter abundance in our study areas just prior to or just following the spill. Surveys of sea otter abundance along the 


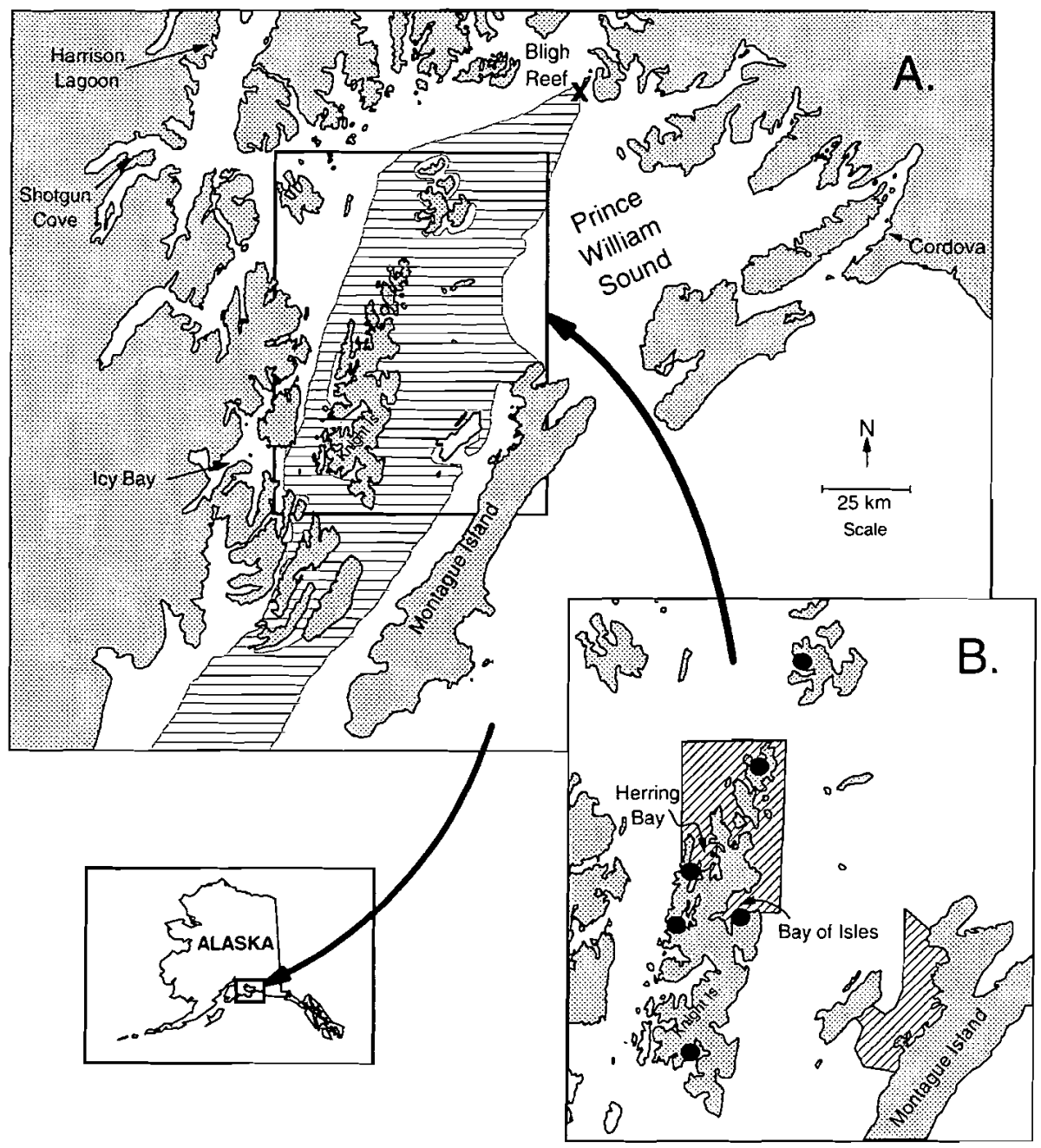

Fig. 1. Location of sampling sites for sea otters, sea urchins, and kelp in western Prince William Sound. The trajectory of oil from the Exxon Valdez oil spill is given by the hatched area in (A). This is based on a hind-cast model (Galt et al. 1991) and shoreline oiling surveys (ADEC 1989, ADNR 1991). Survey areas for sea otters are indicated by hatching in (B). Sea urchins were sampled at systematically placed sites along the shorelines in Herring Bay, Bay of Isles, and the hatched area of Montague Island in 1996 and 1997. (1) Sites where kelp and sea urchin density were sampled in 1990, 1993, and 1998

shoreline, conducted from a small boat as an adjunct to sea bird surveys (Burn 1994, unpubl., Johnson \& Garshelis 1995), were previously used to estimate the decline in sea otters that resulted from the spill (Garrott et al. 1993, DeGange et al. 1995, Johnson \& Garshelis 1995). However, during times when concurrent estimates for the same areas were available for both methods (July 1993, 1996, and 1998), means from aerial surveys differed from boat survey estimates by a factor of 0.3 to 3.6. Boat survey estimates were higher than the aerial survey means in 3 instances and lower in another 3 instances. We chose not to rely on boat survey data because (1) there are known biases in the boat survey methods (Udevitz et al. 1995), (2) boat surveys sampled a smaller proportion of sea otter habitat (generally on the order of $6 \%$ vs about $20 \%$ for aerial surveys) and inaccuracies were likely to result from small-scale shifts in the distribution of otters, and (3) boat survey estimates did not agree closely with estimates from aerial surveys, which are considered to be more accurate. As a result, we cannot be certain of the relative decline in sea otter density caused by the oil spill. However, the number of sea otters removed from northern Knight Island in 1989 can be estimated, and based on this, we estimate the minimum population density prior to the spill. The number of sea otters removed is probably a close approximation of the prespill density given that mortality of sea otters in this region was high (Bodkin \& Udevitz 1994) and that considerable effort was made to remove any surviving otters from here because they were either oiled or at risk of being oiled (Bodkin \& Weltz 1990). 
The number of sea otters removed as a result of the spill is based on the number of carcasses recovered, an estimate of the number of carcasses that were not recovered, and the number of sea otters removed for rehabilitation. We assumed that the number of carcasses drifting out of the study area equaled the number drifting in, and we excluded fetuses and sea otters judged to have died prior to the spill. A number of recovered carcasses and live sea otters removed for rehabilitation, all of which were taken from the sound, did not have specific collection sites identified. We assumed that the proportion of these that was from our study area was equal to the proportion of sea otters with known collection sites that came from our study area. We estimate that $59 \%$ of the dead sea otters were recovered. This was based on the model of Garshelis (1997), which estimated carcass recovery rate based on the proportion of beaches that were searched, and the likelihood of finding a beached carcass on searched beaches. DeGange et al. (1994) gave a lower estimate $(20 \%)$, but this was for the entire spill area, including locations outside of the sound, where search efforts and hence carcass recovery rates were lower. The number of otters removed, compared to the number of otters observed at northern Knight Island in 1993 through 1998, gave a minimum relative reduction in otter abundance that occurred following the spill and was sustained for years afterwards.

Sea urchins in areas of high and low sea otter density, 1996 and 1997. Sea urchin density and size distributions were compared between a heavily oiled area with reduced sea otter densities and an unoiled area where sea otter densities were unaffected by the spill and remained high. Densities and size distributions were estimated from approximately $68 \mathrm{~km}$ of shoreline in Bay of Isles and Herring Bay, on northern Knight Island, and along approximately $51 \mathrm{~km}$ of shoreline on Montague Island (Fig. 1). These were subsets of the areas in which aerial sea otter surveys were conducted. Twenty-nine to 30 different, systematically selected shoreline segments, each $200 \mathrm{~m}$ long, were sampled in each year. On each selected segment, we sampled on randomly placed transects placed within each of 3 depth strata: deep subtidal $(-5$ to $-10 \mathrm{~m})$, shallow subtidal $(-0.5$ to $-5 \mathrm{~m})$, and intertidal $(+0.5$ to $-0.5 \mathrm{~m})$. All depths are relative to mean lower-low water. Subtidal transects were sampled by divers. Sea urchins from within a $50 \mathrm{~m}$ long by $0.5 \mathrm{~m}$ wide transect, placed parallel to shore, were counted and measured. All movable rocks were turned to search for sea urchins. We could confidently find sea urchins approximately $5 \mathrm{~mm}$ or greater, but smaller individuals were difficult to see and were not sampled. Biomass of sea urchins was estimated based on a regression of dry mass versus test diameter from a subsample of 62 sea urchins ranging in size from 5.0 to $46.8 \mathrm{~mm}$. The resulting function was: dry mass $(\mathrm{g})=0.00065$ (test diameter $[\mathrm{mm}])^{2.52}, \mathrm{r}^{2}=0.96$.

We also measured sea urchin density in the lower intertidal zone along gently sloping cobble beaches, where we observed widely scattered aggregations of sea urchins that were unlikely to be adequately characterized by our systematic sampling. Based on a visual shoreline census made from a boat, and on aerial photographs, we identified $3100 \mathrm{~m}$ and $2200 \mathrm{~m}$ of shoreline fitting this description within the Knight and Montague Island study areas, respectively. These shorelines were divided into $100 \mathrm{~m}$ segments, and 4 segments from each study area thought to be the most promising sea urchin habitats were sampled along with 8 (at Knight Island) and 9 (at Montague Island) additional randomly selected segments. Six of the 12 segments at Knight Island and 3 of the 13 segments at Montague Island had aggregations of sea urchins. We marked the boundaries and estimated the areal extent of each aggregation, and based on the size and relative density of sea urchins observed, either censused the entire aggregation or sampled within randomly placed quadrats or transects to estimate sea urchin density.

Sea urchins and kelp in an area of reduced sea otter abundance, 1990 to 1998 . The density of sea urchins and the percent cover and biomass (blotted wet weight) of kelp were measured at sites in 6 bays within the general region of Knight Island (Fig. 1). The extent of shoreline oiling at these sites varied, but all were within the oil spill's trajectory where the density of sea otters was reduced following the spill. These sites were used to estimate oil spill impacts on kelp and invertebrates in 1990 (Dean et al. 1996a,b) and re-sampled in the summers of 1993 and 1998. There is no comparable time series for sea urchin density from Montague Island, and no kelp density data from Montague Island. Sea urchins were counted within a $2 \mathrm{~m}$ swath along each of three $30 \mathrm{~m}$ long transects at each site. Visual estimates of percent cover of kelp were made in 4 randomly placed $0.25 \mathrm{~m}^{2}$ quadrats on each transect and the kelp within each quadrat were counted by species and harvested for determination of biomass (blotted wet mass). Transects were placed at random positions along the shore and at a random depth between 2 and $11 \mathrm{~m}$. Different randomly selected transect locations were sampled in each year.

Statistical analyses. We tested the null hypothesis of no difference in sea otter density between areas, among years, and their interaction with a 2-way, fixedeffect ANOVA. Only data from 1995 through 1998, in which replicate surveys were conducted, were used in the analysis. Estimates of density from each replicate survey were square-root arcsine transformed to equalize variances. Assumptions of normality and homo- 
geneity of variance were met once data were transformed. Bonferroni's multiple comparisons (Milliken \& Johnson 1984) were used to contrast years within each study area.

Sea urchins were patchily distributed, and were found at only a small proportion of systematically selected shoreline segments that were sampled. As a result, we were unable to statistically test hypotheses of differences in mean density. Instead, we tested the hypothesis of no differences in the frequency of occurrence of sea urchins between depth strata, sampling areas, years, and their interaction with a 3-way log-linear model (Grizzle et al. 1969) using the SAS ${ }^{\circledR}$, catmod procedure (SAS 1988). We also tested the hypotheses that, at intertidal sampling sites where sea urchins were present, there was no difference in mean density between areas and years, and no interaction between area and year. Densities were log-transformed in order to equalize variances.

The hypothesis of no difference in the proportion of large sea urchins ( $>20 \mathrm{~mm}$ test diameter) between areas and years was tested using a log-linear analysis as described above. A $20 \mathrm{~mm}$ size category was selected because sea otters are size-selective predators, and when larger sea urchins are available, they generally prey on individuals larger than $20 \mathrm{~mm}$ (Estes \& Duggins 1995). All sea urchins collected from each area were pooled to obtain a reasonable sample size.

Temporal trends in the density, percent cover, and biomass of kelp within the Knight Island area were examined using a 1-way ANOVA. Sites were treated as experimental units and site means were used as replicates. All data met assumptions of normality and homogeneity of variance, and no transformation of the data was required.

\section{RESULTS}

\section{Sea otter abundance}

The average density of sea otters at northern Knight Island between 1993 and 1998 was 0.46 ind. $\mathrm{km}^{-2}$ (77 ind. in a $168 \mathrm{~km}^{2}$ area), roughly one-third of the 1973 pre-spill estimate of 1.41 ind. $\mathrm{km}^{-2}$ (Fig. 2). In contrast, pre- and post-spill population estimates from Montague Island were similar, averaging 5.37 ind. $\mathrm{km}^{-2}$ in 1973, compared to 5.21 ind. $\mathrm{km}^{-2}$ between 1993 and 1998. From 1995 through 1998, the average density of sea otters at northern Knight Island was the same as in 1993 (0.46 ind. $\mathrm{km}^{-2}$ ) and there was no significant change in density with time. On the other hand, sea otter densities at Montague Island increased significantly between 1996 and 1997. Even prior to the oil spill, sea otter densities were higher at Montague,

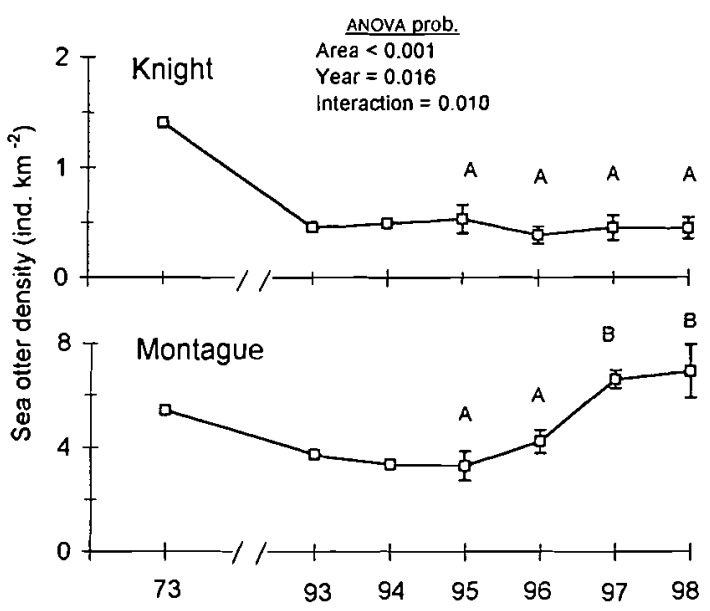

Fig. 2. Population estimates for sea otters in the northern Knight and Montague Island study areas between 1973 and 1998. Replicate surveys were conducted in each year between 1995 and 1998, and error bars are given representing \pm 1 standard error. The number of surveys conducted varied from 5 (in 1995 through 1997) to 6 (in 1998) at Montague Island, and from 4 (in 1995, 1997, and 1998) to 5 (in 1996) at Knight Island. Results of a 2-way ANOVA conducted to test for differences between areas (Montague and Knight Islands), years (1995 to 1998), and their interaction are given. Like letters indicate yearly means within each area that did not differ significantly based on Bonferroni contrasts of years within areas. Note the difference in scales for Montague and Knight Islands

probably because shorelines are less steeply sloped there and there is proportionally more shallow water where sea otters prefer to feed. After the oil spill, the magnitude of the difference between islands was greater, averaging about a full order of magnitude.

An estimated 165 sea otters were removed from the northern Knight Island area subsequent to the oil spill in 1989 (Fig. 3). Sixty-one oiled sea otter carcasses were recovered from northern Knight Island. We estimate that an additional 24 of the carcasses with unspecified Prince William Sound collection sites came from this area. An estimated 60 sea otter carcasses were not recovered. In addition, 17 sea otters were removed from this study area for rehabilitation. Finally, we estimated that 3 sea otters in rehabilitation with unidentified collection sites came from the study area. This totals 165 sea otters $\left(0.98\right.$ ind. $\mathrm{km}^{-2}$ ) that were removed from the northern Knight Island area. We use this estimate as the minimum pre-spill sea otter density within this area. Based on this minimum, and on the number of sea otters present in 1993 (77), we estimate that there was a relative reduction in sea otter density of at least $53 \%$ as a result of the spill. There was a $68 \%$ decline in sea otter abundance between 1973 and 1993, but some of this may have occurred prior to the spill in 1989. Alternatively, the numbers of 
Table 1. Percentage of sites with sea urchins Strongylocentrotus droebachiensis present and geometric mean densities (backtransformed means of $\log \left[\right.$ ind. $\left.\left.\mathrm{m}^{-2}+0.1\right]\right)$ of sea urchins within northern Knight and Montague Islands, 1996 and 1997. MLLW: mean lower-low water

\begin{tabular}{|lccccc}
\hline Depth stratum & Area & Year & n & $\begin{array}{c}\text { \% with sea } \\
\text { urchins }\end{array}$ & $\begin{array}{c}\text { Geometric mean } \\
\text { density (ind. } \mathrm{m}^{-2} \text { ) }\end{array}$ \\
\hline Intertidal & Knight & 1996 & 30 & 53.3 & 0.039 \\
(+0.5 to -0.5 m, MLLW) & & 1997 & 30 & 26.6 & 0.014 \\
& Montague & 1996 & 30 & 20.0 & 0.007 \\
Shallow subtidal & & 1997 & 29 & 48.3 & 0.055 \\
(-0.5 to -5.0 m, MLLW) & Knight & 1996 & 30 & 10.0 & 0.003 \\
& & 1997 & 30 & 10.0 & 0.003 \\
Deep subtidal & Montague & 1996 & 30 & 3.3 & 0.001 \\
(-5.0 to-10.0 m, MLLW) & & 1997 & 28 & 14.3 & 0.004 \\
& Knight & 1996 & 30 & 10.0 & 0.002 \\
& Montague & 1997 & 29 & 3.4 & 0.001 \\
& & 1996 & 24 & 0.0 & 0.000 \\
\end{tabular}

sea otters could have been higher at northern Knight Island before the spill in 1989 than in 1973.

\section{Sea urchin density, size distribution, and biomass}

In 1996 and 1997, sea urchins were relatively rare at both the northern Knight Island and Montague study areas. On systematically selected transects, the geometric mean density within every depth stratum, area, and year was less than 0.06 ind. $\mathrm{m}^{-2}$ (Table 1). In almost all cases, sea urchins were found under cobble or boulders, and were not visible unless rocks were overturned. There was a significant interaction in the frequency of occurrence of sea urchins between areas

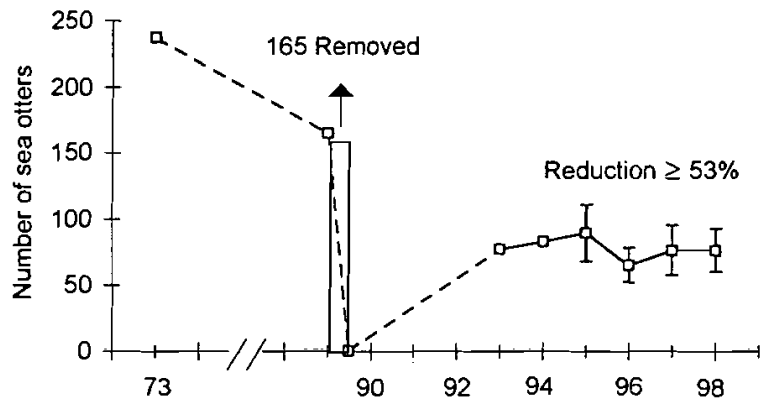

Fig. 3. Numbers of sea otters at northern Knight Island, Prince William Sound, between 1973 and 1998. The 1973 value is from an aerial census. Estimates from 1993 to 1998 are from aerial surveys. Replicate surveys ( $n=4$ in 1995, 1997, and $1998 ; \mathrm{n}=5$ in 1996) were conducted after 1994 and means \pm 1 standard error are given for these. The 1989 data are minimum values based on the estimated number of sea otters removed from the area as a result of the Exxon Valdez oil spill. The dashed line indicates uncertainty in trends that result from having only estimated minimums in 1989 and years (Table 2). Sea urchins were found at significantly more sites at northern Knight Island than at Montague Island in 1996, but the frequency of occurrence did not differ between areas in 1997 (Tables 1 \& 2 ). Overall effects of area (over both years) and year (over both areas) were not significant. The frequency of occurrence of sea urchins was higher in the intertidal zone than in the subtidal (both shallow and deep strata) at both northern Knight and Montague Islands. At intertidal sites with sea urchins present, densities were significantly higher in 1997 than in 1996, but there were no differences in density between northern

Table 2. Results of log-linear categorical analysis of the frequency of occurrence of sea urchins Strongylocentrotus droebachiensis within different depth strata (intertidal, shallow subtidal, deep subtidal), areas (Knight and Montague Islands), and years (1996 and 1997)

\begin{tabular}{|c|c|c|c|}
\hline Source & df & Chi-square & $\mathrm{p}$ \\
\hline Intercept & 1 & 2069.30 & $<0.001$ \\
\hline Depth stratum & 2 & 46.47 & $<0.001$ \\
\hline Area & 1 & 1.05 & 0.305 \\
\hline Year & 1 & 0.23 & 0.629 \\
\hline Depth stratum $\times$ Area & 2 & 0.29 & 0.867 \\
\hline Depth stratum $\times$ Year & 2 & 0.86 & 0.649 \\
\hline Area $\times$ Year & 1 & 12.20 & $<0.001$ \\
\hline Depth stratum $\times$ Area $\times$ Year & 2 & 5.69 & 0.058 \\
\hline \multicolumn{4}{|l|}{ Contrasts between depth strata } \\
\hline Intertidal vs shallow & 1 & 29.51 & $<0.001$ \\
\hline Intertidal vs deep & 1 & 46.24 & $<0.001$ \\
\hline Shallow vs deep & 1 & 1.91 & 0.167 \\
\hline \multicolumn{4}{|l|}{ Contrasts of areas within years } \\
\hline Knight vs Montague (1996) & 1 & 9.82 & 0.002 \\
\hline Knight vs Montague (1997) & 1 & 2.74 & 0.090 \\
\hline
\end{tabular}


Knight and Montague Islands (Fig. 4). Geometric means were less than 0.5 ind. $\mathrm{m}^{-2}$ in both areas.

Higher densities of sea urchins were found within widely spaced aggregations, especially on Knight Island. Searches of gently sloping intertidal cobble beaches in 1996 revealed 6 such aggregations at Knight Island and 3 at Montague Island. The geometric mean density within these aggregations was 12.11 ind. $\mathrm{m}^{-2}$ at Knight Island and 0.42 ind. $\mathrm{m}^{-2}$ at Montague Island and differed significantly between areas (Student's $t=5.88, \mathrm{p}<0.01$ ). The average areal extent of aggregations was about 2.5 times higher at Knight Island (mean $=253 \mathrm{~m}^{2}$ at Knight Island and $104 \mathrm{~m}^{2}$ at Montague Island) but did not differ significantly between areas (Student's $t=1.92, \mathrm{p}=0.096$ ).
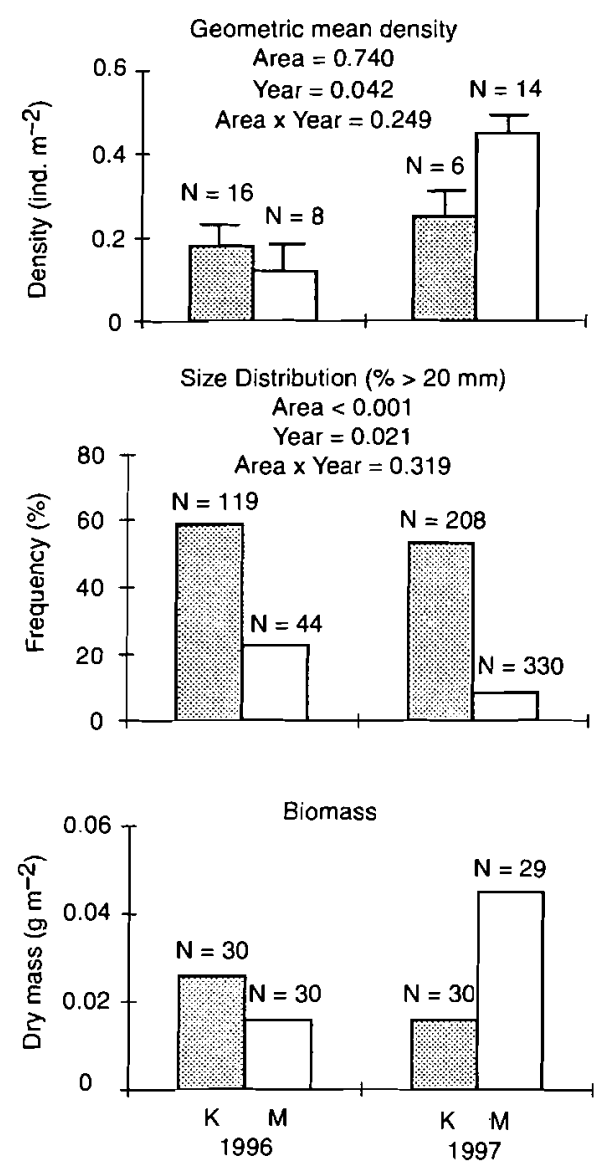

Fig. 4. Density, size distribution, and the mean biomass of sea urchins Strongylocentrotus droebachiensis at northern Knight (K) and Montague (M) Islands in 1996 and 1997. Density values are geometric means (plus 1 standard error) for those intertidal sites where sea urchins were present. Size distributions are expressed as the percentage of sea urchins with test diameters greater than $20 \mathrm{~mm}$. Results of a 2-way ANOVA (for density) or a 2-way log-linear analysis (for size distribution) are given

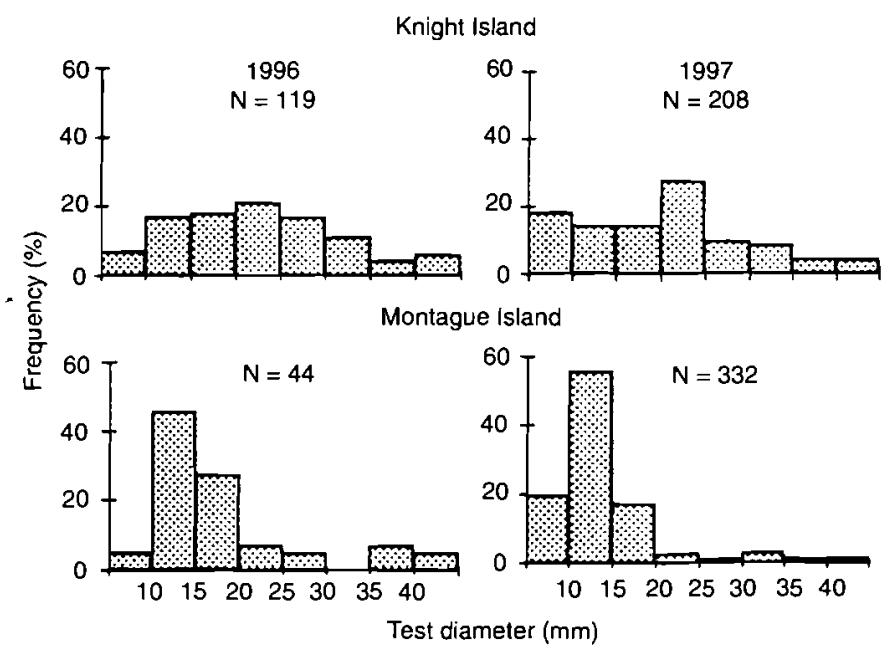

Fig. 5. Size-frequency distribution of sea urchins Strongylocentrotus droebachiensis at northern Knight and Montague Islands in 1996 and 1997

Few large sea urchins were found at either northern Knight or Montague Islands (Fig. 5). The largest sea urchin had a test diameter of $53 \mathrm{~mm}$. Only $4.9 \%$ at Knight lsland and $2.9 \%$ from Montague Island were greater than $40 \mathrm{~mm}$ (based on averaged percentages from 1996 and 1997). The majority of the sea urchins from Montague Island were $15 \mathrm{~mm}$ or less, and the majority from Knight Island were $25 \mathrm{~mm}$ or less. Sizefrequency distributions differed between areas, and the proportion of sea urchins that were larger than $20 \mathrm{~mm}$ was higher at Knight Island than at Montague Island (Fig. 4). Also, there were significantly higher frequencies of large sea urchins in 1996 than in 1997 (Fig. 4).

The biomass of sea urchins was low at both northern Knight and Montague Islands, averaging less than $0.06 \mathrm{~g}_{\text {dry mass }} \mathrm{m}^{-2}$ at both areas in 1996 and 1997 (Fig. 4). We were unable to test for statistical differences in biomass between areas and years because there were no urchins found at a large number of sites. However, the range in yearly mean biomass overlapped between areas and mean biomass was higher at Knight in 1996 and higher at Montague in 1997 (Fig. 4).

\section{Temporal trends in sea urchins and kelp in an area of reduced sea otter density}

Within the area where sea otter densities were reduced, densities of sea urchins remained low and kelp densities remained high in 1990, 1993, and 1998. Geometric mean densities of sea urchins in subtidal surveys conducted at 6 sites within the Knight Island 
Table 3. Geometric mean density of sea urchins Strongylocentrotus droebachiensis at 6 subtidal sites within the Knight Island. Also given are mean biomass, percent cover, and density of kelp greater than $10 \mathrm{~cm}$ in height at these sites in 1990 , 1993, and 1998. Standard errors are given in parentheses. Also given are probabilities of no difference in means between years based on 1-way ANOVAs. No test was performed for sea urchin data because of the large number of sites without sea urchins. All sites had reduced densities of sea otters

\begin{tabular}{|c|c|c|c|c|}
\hline Year & $\begin{array}{c}\text { Sea urchin } \\
\text { geometric mean } \\
\text { density (ind. } \mathrm{m}^{-2} \text { ) }\end{array}$ & $\begin{array}{c}\text { Kelp biomass } \\
\text { (g wet mass } \mathrm{m}^{-2} \text { ) }\end{array}$ & $\begin{array}{c}\text { Kelp } \\
\text { cover } \\
(\%)\end{array}$ & $\begin{array}{l}\text { Kelp density } \\
\text { (ind. } \mathrm{m}^{-2} \text { ) }\end{array}$ \\
\hline 1990 & 0.007 & $1449(222)$ & $62.9(3.06)$ & $8.28(0.85)$ \\
\hline 1993 & 0.015 & $1222(313)$ & $66.4(8.02)$ & $12.67(4.49)$ \\
\hline 1998 & 0.002 & 908 (229) & $53.3(6.13)$ & $10.89(2.39)$ \\
\hline $\mathbf{p}$ & No test & 0.290 & 0.272 & 0.499 \\
\hline
\end{tabular}

rarer, but suggest that prey often respond in a non-linear manner to changes in predator abundance (Hurd \& Eisenberg 1984, Andrew \& Underwood 1993, Fagan \& Hurd 1994). Even in cases where keystone predators are completely removed from a system, community responses may vary with location or time (reviewed in Power et al. 1996). Understanding the range in variation in response and the causes for this is important for understanding functional relationships between predator and prey and, in particular, in predicting how systems may respond to perturbations of predators.

In rocky subtidal systems of the North Pacific, it has been widely demonstrated that where sea otters are abundant large sea urchins are rare and kelp is abundant. The alternative state is represented by no sea otters, higher densities of large sea urchins, and less abundant kelp (Lowry \& Pearse 1973, Estes \& Palmisano 1974, Estes et al. 1978, 1998, Duggins 1980 , Breen et al. 1982, Laur et al. 1988, Watson 1993, Estes \& Duggins 1995, Kvitek et al. 1998). The response of communities during transitions in sea otter abundance (from either low to high or vice versa) is less predictable. In some cases, sea urchin densities have dramatically declined and kelp abundance has increased within a few months of sea otter reoccupation (Laur et al. 1988, Watson 1993). However, little response was observed in the $10 \mathrm{yr}$ following reoccupation by sea otters in the Semichi Islands, Alaska (Konar 2000). An approximate $90 \%$ reduction in sea otters in the western Aleutian Islands was followed by a 9 -fold increase in sea urchin Strongylocentrotus polyacanthus biomass and a nearly $90 \%$ reduction in kelp (Estes et al. 1998). In contrast, in both the Knight Island area of Prince William Sound (our study) and the Semichi Islands (Konar 2000), a reduction in sea otter abundance on the order of $50 \%$ resulted in no apparent effect on sea urchin biomass, and little or no change in kelp abundance.

Differences in community response to changes in predator abundance may relate in part to the magnitude of the change and the non-linear nature of the response by prey. Both the relative and absolute reductions in sea otter population density observed by Estes et al. (1998) in the western Aleutian Islands were apparently larger than those we observed in Prince William Sound. While reductions in sea otter abundance in heavily oiled parts of Prince William Sound may have approached or exceeded $90 \%$ immediately following the oil spill in 1989, we estimate that the population density was about one-third of the pre-spill 
(1973) density in 1993 to 1998 . The number of remaining sea otters may have been high enough to inhibit sea urchin population growth in our study areas, but not in the western Aleutian Island sites. Even though sea urchin densities within our study areas were low, sea otters continued to prey on sea urchins. In a collection of 102 sea otter scats from western Prince William Sound in winter $1998,29 \%$ had sea urchin remains (J.L.B. unpubl. data). The continuing effect of sea otter predation in our study area was reflected in the size distributions of sea urchins. While there were proportionally more large urchins where sea otter densities were reduced on northern Knight Island, there were very few large sea urchins in either of our study areas.

Differences in community response to changes in sea otter abundance may also result from what has been termed context dependence (Power et al. 1996). The role of a keystone predator can vary with location or time (reviewed in Power et al. 1996), and may depend on the relative frequency or magnitude of recruitment of prey (Menge et al. 1994, Robles 1997). The difference in response to a reduction in sea otters in Prince William Sound versus the western Aleutian Island sites examined by Estes et al. (1998) may have been related to the much higher density of small sea urchins in the Aleutians that was maintained even in the presence of sea otters. Prior to the reduction in sea otters in the western Aleutians, sea urchin densities were upwards of 100 ind $\mathrm{m}^{-2}$, even where sea otters were abundant for decades (Estes \& Duggins 1995). In contrast, densities in Prince William Sound averaged less than 0.06 ind. $\mathrm{m}^{-2}$, and even in denser inter-tidal aggregations on Knight Island, averaged only 12 ind. $\mathrm{m}^{-2}$.

The relatively low density of small sea urchins observed in Prince William Sound is similar to that observed by Estes \& Duggins (1995) in Southeast Alaska. At locations near Sitka where there were few sea otters, Estes \& Duggins found high densities of large sea urchins, with relatively few smaller individuals. At nearby sites that sea otters had recently colonized, almost all of the sea urchins were eaten and very few individuals remained. They attributed the relative lack of small sea urchins at Southeast Alaska sites compared to the Aleutians to a relative lack of sea urchin recruitment. We have not measured recruitment in Prince William Sound, but it is likely that the relatively low density of small sea urchins, and the lack of response to reductions in sea otters, may be related to relatively low frequency of widespread sea urchin recruitment.

While we suspect that Prince William Sound may support lower rates of sea urchin recruitment than the western Aleutians, there is ample evidence to suggest that sea urchin abundance in Prince William Sound would be higher in the total absence of sea otters. A survey conducted in northern Prince William Sound in 1984 found extremely high densities of relatively large sea urchins in Shotgun Cove, an area not yet reoccupied by sea otters (D. M. Irons, J.L.B. and G. R. VanBlaricom unpubl. data). Densities of sea urchins exceeded $1000 \mathrm{~m}^{-2}$ in some areas, $7.8 \%$ were over $40 \mathrm{~mm}$ test diameter, and the maximum size was $57 \mathrm{~mm}$. In contrast, in nearby Harrison Lagoon, which was recently recolonized by sea otters, sea urchin densities were high (maximum of $296 \mathrm{~m}^{-2}$ ) but all were small (mean test diameter $<15 \mathrm{~mm}$ and maximum test diameter $=29 \mathrm{~mm}$ ). Second, we observed 2 large aggregations of sea urchins during the course of our studies: 1 in Bay of Isles and 1 in the mouth of Icy Bay. In 1995, preliminary observations suggested that maximum densities in these aggregations were in the range of 20 to $50 \mathrm{~m}^{-2}$. Mean test diameters were about $25 \mathrm{~mm}$, near the minimum size usually consumed by sea otters (Estes \& Duggins 1995). Each aggregation covered an area of $100 \mathrm{~m}^{2}$ or more. In spite of obtaining accurate positions for these aggregations, we were unable to relocate any sea urchins at these sites when we returned to do more quantitative surveys in subsequent years. Finally, in 1998, over 700 small (mean test diameter $<20 \mathrm{~mm}$ ) sea urchins were found in several trawl samples from depths of about $30 \mathrm{~m}$ at Montague Island (D.H.M. \& A. Fukuyama unpubl. data). The area sampled and the efficiency of the trawl could not be accurately determined, making it impossible to accurately estimate sea urchin density. However, it is likely that the density of sea urchins was over $1 \mathrm{~m}^{-2}$, and probably much higher. These observations suggest that Prince William Sound is capable of supporting locally dense patches of sea urchins, and in the absence of sea otters, sea urchins within these patches can grow to $40 \mathrm{~mm}$ or more.

Predation on sea urchins by sea stars and birds may also have contributed to the apparent lack of response by sea urchins to reductions in sea otters. Sunflower sea stars Pycnopodia helianthoides and glaucouswinged gulls Larus glaucescens are known predators of sea urchins (Duggins 1980. Irons et al. 1986) and both are abundant in Prince William Sound (Wiens 1995, Dean et al. 1996a). P. helianthoides densities averaged more than $0.1 \mathrm{~m}^{-2}$ in rocky subtidal habitats, and were greater than $1 \mathrm{~m}^{-2}$ at some sites (Dean et al. 1996a). In the intertidal zone, densities of adult $P$. helianthoides averaged $0.16 \mathrm{~m}^{-2}$ at Knight Island and were significantly higher than the $0.03 \mathrm{~m}^{-2}$ at our Montague Island sites ( $<<0.01, t$-test, T.A.D. \& S.C.J. unpubl. data). Sea urchins are rarely found in the stomachs of $P$. helianthoides collected from Prince William Sound (Gage 1998, S.C.J. unpubl. data), but we cannot rule out that sea star or bird predation helped to limit sea urchin populations. 
We also cannot dismiss the possibility that the lack of a stronger response by sea urchins in Prince William Sound was related, in part, to impacts associated with the oil spill. While Dean et al. (1996a) found no evidence of an impact of oil on sea urchin populations, very few sea urchins were found at either oiled or unoiled sites, and the power to detect differences was low. For several more abundant intertidal and subtidal invertebrates, for which differences were more easily detected, higher densities were observed in unoiled versus heavily oiled areas (Dean et al. 1996a, Highsmith et al. 1996, Jewett et al. 1999).

While we observed no substantial increase in sea urchin biomass or decrease in kelp biomass in the 9 yr following the reduction in sea otters in 1989, future changes are possible. The number of sea otters at northern Knight Island has remained low, and a strong recruitment year for sea'urchins could result in an increase in sea urchin biomass. Thus, we may have observed a long lag in response to a reduction in predators, rather than a lack of response. Such lags are expected in cases where recruitment of prey is episodic.

Acknowledgements. We thank Brenda Ballachey and George Esslinger for assistance in conducting sea otter surveys and for analyzing these data, and Chris Bonner, Max Hoberg, John Moreland, Jerry Phillips, and Susan Saupe for assisting in sea urchin and kelp surveys. The manuscript benefited by reviews of an earlier draft by Jim Estes, Dan Reed, Glenn VanBlaricom, and anonymous reviewers. The work was supported by the Alaska Biological Science Center, US Geological Survey, the Alaska Department of Fish and Game, and the Exxon Valdez Oil Spill Trustee Council. The findings and conclusions presented by the authors, however, are their own and do not necessarily reflect the views or opinions of the supporting organizations.

\section{LITERATURE CITED}

ADEC (Alaska Department of Environmental Conservation) (1989) Impact maps and summary reports of shoreline surveys of the Exxon Valdez spill site-Prince William Sound. Report to the Exxon Valdez Oil Spill Trustee Council, Anchorage

ADNR (Alaska Department of Natural Resources) (1991) The Exxon Valdez oil spill natural resource damage assessment and restoration: report on oiling to environmentally sensitive shorelines. Report to the Exxon Valdez Oil Spill Trustee Council, Anchorage

Andrew NL, Underwood AJ (1993) Density dependent foraging in the sea urchin Centrostephanus rodgersiu on shallow subtidal reefs in New South Wales, Australia. Mar Ecol Prog Ser 99:89-98

Bodkin JL, Udevitz MS (1994) An intersection model for estimating sea otter mortality along the Kenai Peninsula. In: Loughlin $T$ (ed) Marine mammals and the Exxon Valdez. Academic Press, San Diego, p 81-95

Bodkin JL, Udevitz MS (1999) An aerial survey method to estimate sea otter abundance. In: Garner GW, Amstrup SC, Laake JL, Manly BJF, McDonald LL, Robertson DG (eds) Marine mammal survey and assessment methods. AA Balkema, Rotterdam, p 13-26

Bodkin JL, Weltz F (1990) A summary and evaluation of sea otter rescue operations in response to the Exxon Valdez oil spill, Prince William Sound, Alaska, 1989. In: Bayha K, Kormendy J (technical coordinators) Sea otter symposium: proceedings of a symposium to evaluate the response effort on behalf of sea otters after the T/V Exxon Valdez oil spill into Prince William Sound, Anchorage, Alaska, 17-19 April 1990. US Fish Wildl Serv Biol Rep 90. US Fish and Wildlife Service, Washington, DC, p 61-69

Bodkin JL, Burdin AM, Ryazanov DA (2000) Age- and sexspecific mortality and population structure in sea otters. Mar Mamm Sci 16:201-219

Breen PA, Carson TA, Foster JB, Stewart EA (1982) Changes in subtidal community structure associated with British Columbia sea otter transplants. Mar Ecol Prog Ser 7:13-20

Burn DM (1994) Boat-based surveys of sea otters in Prince William Sound. In: Loughlin T (ed) Marine mammals and the Exxon Valdez. Academic Press, San Diego, p 61-80

Calkins DG (1978) Feeding behavior and major prey species of the sea otter, Enhydra lutris, in Montague strait, Prince William Sound, Alaska. US Fish Bull 76:125-131

Dean TA, Jewett SC, Laur DR, Smith RO (1996a) Injury to epibenthic invertebrates resulting from the Exxon Valdez oil spill. In: Rice SD, Spies RB, Wolfe DA, Wright BA (eds) Proceedings of the Exxon Valdez oil spill symposium. Am Fish Soc Symp 18. American Fisheries Society, Bethesda, p 424-429

Dean TA, Stekoll MS, Smith RO (1996b) Kelps and oil: the effects of the Exxon Valdez oil spill on subtidal algae. In: Rice SD, Spies RB, Wolfe DA, Wright BA (eds) Proceedings of the Exxon Valdez oil spill symposium. Am Fish Soc Symp 18. American Fisheries Society, Bethesda, p 412-423

DeGange AR, Doroff AM, Monson DH (1994) Experimental recovery of sea otter carcasses at Kodiak Island, Alaska following the Exxon Valdez oil spill. Mar Mamm Sci 10: 492-496

DeGange AR, Douglas DC, Monson DH, Robbins CM (1995) Surveys of sea otters in the Gulf of Alaska in response to the Exxon Valdez oil spill. Exxon Valdez oil spill state/federal natural resource damage assessment final report, marine mammal study 6-7. Report to the Exxon Valdez Oil Spill Trustee Council, Anchorage

Doroff AM, Bodkin JL (1994) Sea otter foraging behavior and hydrocarbon levels in prey. In: Loughlin $\mathrm{T}$ (ed) Marine mammals and the Exxon Valdez. Academic Press, San Diego, p 193-208

Duggins DO (1980) Kelp beds and sea otters: an experimental approach. Ecology 61:447-453

Estes JA, Palmisano JF (1974) Sea otters: their role in structuring nearshore communities. Science 185:1058-1060

Esstes JA, Duggins DO (1995) Sea otters and kelp forests in Alaska: generality and variation in a community ecological paradigm. Ecol Monogr 65:75-100

Estes JA, Smith NS, Palmisano JF (1978) Sea otter predation and community organization in the western Aleutian Islands, Alaska. Ecology 59:822-833

Estes JA, Tinker MT, Williams TM, Doak DF (1998) Increasing food chain length and the collapse of kelp forest ecosystems in western Alaska. Science 282:3473-3476

Fagan WF, Hurd LE (1994) Hatch density variation of a generaiist arthropod predator: population consequences and community impact. Ecology 2022-2032

Gage TK (1998) Effects of invertebrate predators on clam 
populations in Prince William Sound, Alaska, with implications for the recovery of sea otters from the Exxon Valdez oil spill. Masters thesis, University of Washington, Seattle

Galt JA, Lehr WJ, Payton DL (1991) Fate and transport of the Exxon Valdez oil spill. Environ Sci Technol 25:202-209

Garrott RA, Eberhardt LL, Burn DM (1993) Mortality of sea otters in Prince William Sound following the Exxon Valdez oil spill. Mar Mamm Sci 9:343-359

Garshelis DL (1997) Sea otter mortality estimated from carcasses collected after the Exxon Valdez oil spill. Conserv Biol 11:905-916

Garshelis DL, Garshelis JA, Kimker AT (1986) Sea otter time budgets and prey relationships in Alaska. J Wildl Manag 50:637-647

Grizzle JE, Starmer CF, Koch GG (1969) Analysis of categorical data by linear models. Biometrics 25:489-504

Haven SB (1971) Effects of land-level changes on intertidal invertebrates, with discussion of postearthquake ecological succession. In: Foy VJ, Bishop EE, Duggan MY, Olnew HA (eds) The great Alaska earthquake of 1964. Vol 4. Biology. National Academy of Science, Washington, DC, p 82-126

Highsmith RC, Rucker TL, Stekoll MS, Saupe SM, Lindeberg MR, Jenne RN, Erickson WP (1996) Impact of the Exxon Valdez oil spill on intertidal biota. In: Rice SD, Spies RB, Wolfe DA, Wright BA (eds) Proceedings of the Exxon Valdez oil spill symposium. Am Fish Soc Symp 18. American Fisheries Society, Bethesda, p 212-237

Hurd LE, Eisenberg RM (1984) Experimental density manipulations of the predator Tenodera sinnensis (Orthoptera: Mantidae) in an old-field community. II. The influence of mantids on arthropod community structure. J Anim Ecol 53:955-967

Irons DB, Anthony RG, Estes JA (1986) Foraging strategies of glaucous-winged gulls in a rocky intertidal community. Ecology 67:1460-1474

Jewett SC, Dean TA, Smith RO, Blanchard A (1999) The Exxon Valdez oil spill: impacts and recovery in the softbottom benthic community in and adjacent to eelgrass beds. Mar Ecol Prog Ser 185:59-83

Johnson CB, Garshelis DL (1995) Sea otter abundance, distribution, and pup production in Prince William Sound following the Exxon Valdez oil spill. In: Wells PG, Butler JN, Hughes JS (eds) Exxon Valdez oil spill: fate and effects in Alaskan waters. ASTM STP 1219. American Society for Testing and Materials, Philadelphia, p 894-929

Konar B (2000) Limited effects of a keystone species: trends of sea otters and kelp forests at the Semichi Islands, Alaska. Mar Ecol Prog Ser 199:271-280

Kvitek RG, Iampietro PJ, Bowlby CE (1998) Sea otters and benthic prey communities: a direct test of the sea otter as a keystone predator in Washington State. Mar Mamm Sci 14:895-902

Editorial responsibility: Charles Peterson (Contributing Editor), Morehead City, North Carolina, USA
Laur DR, Ebeling AW, Coon DA (1988) Effects of sea otter foraging on subtidal reef communities off Central California. In: VanBlaricom GR, Estes JA (eds) The community ecology of sea otters. Springer-Verlag, Berlin, p 151-168

Lensink CJ (1962) The history and status of sea otters in Alaska. PhD thesis, Purdue University, West Lafayette, IN

Lowry LF, Pearse JS (1973) Abalones and sea urchins in an area inhabited by sea otters. Mar Biol 23:213-219

Menge BA, Berlow EL, Blanchette CA, Navarrette SA Yamada SB (1994) The keystone species concept: variation in interaction strength in a rocky intertidal habitat. Ecol Monogr 64:249-286

Milliken GA, Johnson DE (1984) Analysis of messy data, Vol I. Designed experiments. Van Nostrand Reinhold, New York

Pitcher KW (1975) Distribution and abundance of sea otters, Stellar sea lions, and harbor seals in Prince William Sound, Alaska. In: Calkins DG, Pitcher DW, Schneider KB (eds) Distribution and abundance of marine mammals in the Gulf of Alaska. Alaska Deparment of Fish and Game, Anchorage (Appendix A)

Power ME, Tilman D, Estes JA, Menge BA, Bond WJ, Mills LS, Daily G, Castilla JC, Lubchenco J, Paine RT (1996) Challenges in the quest of keystones. BioScience 46: 609-620

Riedman ML, Estes JA (1988) A review of the history distribution and foraging ecology of sea otters. In: VanBlaricom GR, Estes JA (eds) The community ecology of sea otters. Springer-Verlag, Berlin, p 4-21

Robles CD (1997) Changing recruitment in constant species assemblages: implications for predation theory in intertidal communities. Ecology 78:1400-1414

Rosenthal RJ, Lees DC, Rosenthal TM (1977) Ecological assessment of sublittoral plant communities in northern Gulf of Alaska. Final report to NMFS (National Marine Fisheries Service) Auke Bay Laboratory, Juneau

Rosenthal RJ, Lees DC, Maiero DJ (1982) Description of Prince William Sound shoreline habitats associated with biological communities. Final report to the Department of Commerce, NOAA, Office of Pollution Assessment, Juneau

SAS (1988) SAS/STAT ${ }^{\circledR}$, User's guide, Release 6.03. SAS Institute, lnc, Cary

Udevitz MS, Bodkin JL, Costa DP (1995) Detection of sea otters in boat-based surveys of Prince William Sound, Alaska. Mar Mamm Sci 11:59-71

Watson JC (1993) The effects of sea otter (Enhydra lutris) foraging on shallow rocky communities off Northwestern Vancouver lsland, British Columbia. PhD thesis, University of California, Davis

Wiens JA (1995) Recovery of seabirds following the Exxon Valdez oil spill: an overview. In: Wells PG, Butler JN, Hughes JS (eds) Exxon Valdez oil spill: fate and effects in Alaskan waters. ASTM STP 1219. American Society for Testing and Materials, Philadelphia, p 854-893

Submitted: June 22, 1999; Accepted: December 31, 1999 Proofs received from author(s): May 25, 2000 